\title{
Development of Used Car Market in China
}

\author{
Yali Yang, Hao Chen", Ruoping Zhang \\ College of Automotive Engineering, Shanghai University of Engineering Science, Shanghai, China \\ Email: carolyn71@163.com, "pschenhao@163.com, zhangruoping@sues.edu.cn
}

Received April 25, 2013; revised May 25, 2013; accepted June 15, 2013

Copyright (c) 2013 Yali Yang et al. This is an open access article distributed under the Creative Commons Attribution License, which permits unrestricted use, distribution, and reproduction in any medium, provided the original work is properly cited.

\begin{abstract}
Although still in its early development phase, rapid growth of auto ownership has also injected new vitality for used car market in China. Under the support of series policy, the used car market reveals leaping development character with qualified changes. It is essential to understand the new changes in the used car market. This paper conducted research on the new features of used car market in China to promote its development. Environment analysis showed that used car market will be strongly enhanced by the blooming of auto market, rapid GDP growth and policy support, which experienced steady trade scale increase and structure optimization. The used car trade experienced steady trade scale increase and structure optimization. Along with the purchasing pattern changing, significant expansion of the secondhand car market is imminent, even with hinder issues such as lack of integrity, evaluation criteria and after-service system, and incomplete policy and regulation. Several new features were identified, strong policy support, enlarging market scale and irradiation loop, remarkable concentration increase, increased status of brand used car, and enhanced trading service platform establishment. It is indicated that China's used car market is making the shift from subordinate position to one of the dominant positions in auto industry, which is expected into a high speed, up-going development passage in the future.
\end{abstract}

Keywords: Used Car Market; Development; New Features; China

\section{Introduction}

With the rapid social and economical development, China has become one of the most important markets in the world for the automotive industry. In recent years, the scale of China's automotive after-sales service market continues to increase [1]. Analyzing from the policy, market, development potential and other aspects, the Annual Report on Automotive Industry in China (2010) found that, in the "Twelfth Five-Year" period, China's automotive after-sales service market will maintain an annual growth rate of about 8 percent by a conservative estimate, and reach up to about RMB252.3 billion Yuan in 2015 [2].

Contemporarily, the rapid growth of auto ownership has also injected new vitality for second-hand car market. The trading volume of the used car market rose from 370 thousand to 4.33 million from 2001 to 2011, with an annual increase beyond $30 \%$. The average trading ration between used car and new car is 0.24 , which indicates the growing proportion of used car in auto industry [3]. In recent years, such operating models as used car bro-

\footnotetext{
"Corresponding author.
}

kers, used car auction and used car replacement have emerged in the market successively. The alteration of trading models provides new engines for the development of the used car market in China. It is estimated that the trade volume ratio between used and new car would reach 1:1 in the next ten years.

However, China's used car trade market is still in low proportion in the auto industry, even with its rapid growth. According to the experience of western advanced countries, taking USA as an example, the benefits from used car sector accounts for $45 \%$ of the whole auto industry, and the average profit from one used car is around 20\% [4].

Under the support of series policy, the used car market reveals leaping development character with qualified changes. From 2000, China's used car market experience high growth, and gradually became the major part of the auto industry. The used car market already made the shift from the subordinate position to one of the dominant positions in the auto industry. It is vital to understand the new changes in the used car market. Thus this paper conducted research on the new environment of the used car market, probed into its new features, thus to further promote the 
development of the used car market in China.

\section{Environment Analysis}

\subsection{Auto Market Status Analysis}

Due to the rapid development in auto industry, China's auto market is becoming the most important area for auto trade and manufacture. Fast expands was observed in China's auto industry. From 2002 to 2011, auto trade volume rose from 3.25 million to 18.51 billion, increaseing almost 6 times, with $23.5 \%$ annual increment, shown in Figure 1.

Note(s): Red section represents passenger car, yellow section represents commercial car, blue line represents increment for total car trade volume.

Along with the growth in auto trade volume, car is popularized in ordinary family. According to the data from China Automotive Industry Association, civil car population increased from 18.02 million to 93.5 million, with averagely $17.4 \%$ increment per year, shown in Figure 2.

Consequently, the car volume per thousand people grew steadily in China, from 3.7 to 46.8 in 2001 to 2011, increased 12.7 times, shown in Figure 3. According to the auto market development, China's auto market is in the massive popularization stage. In the stage, car volume will keep fast increase until the car volume per thousand people exceeds 250. Usually, it will last 10 years. Due to the regional difference in income, population, economy, this stage may last longer in China. Experts from State Information Center estimated that this stage may last until 2013, with $12 \%$ - 14\% increment annually.

Therefore, the ever growing car volume due to the popularization stage of auto market, will provide more room and solid foundation for used car market development in China.

Therefore, the ever growing car volume due to the popularization stage of auto market, will provide more room and solid foundation for used car market development in China.

\subsection{Economy Environment Analysis}

Development of Auto market is positively related to economy development and people's income [5]. As the biggest population in the world, the market potential is enormous. Recently, China economy keeps steady and fast increase. Real GDP Per Capital increased from $1041 \$$ in 2001 to $5432 \$$ in 2011, with $17.4 \%$ annual increment, shown in Figure 4.

As resident's income level is the key factor for auto population, the fast growth in income will transfer into higher demand increase in China auto market, which will

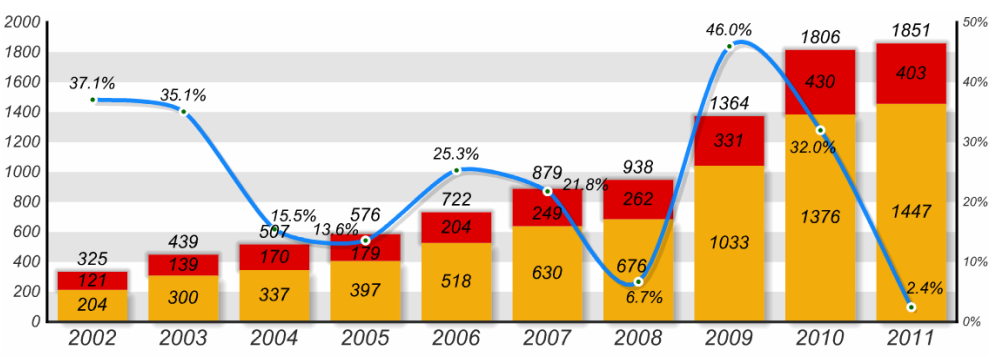

Figure 1. Auto trade volume from 2002 to 2011.

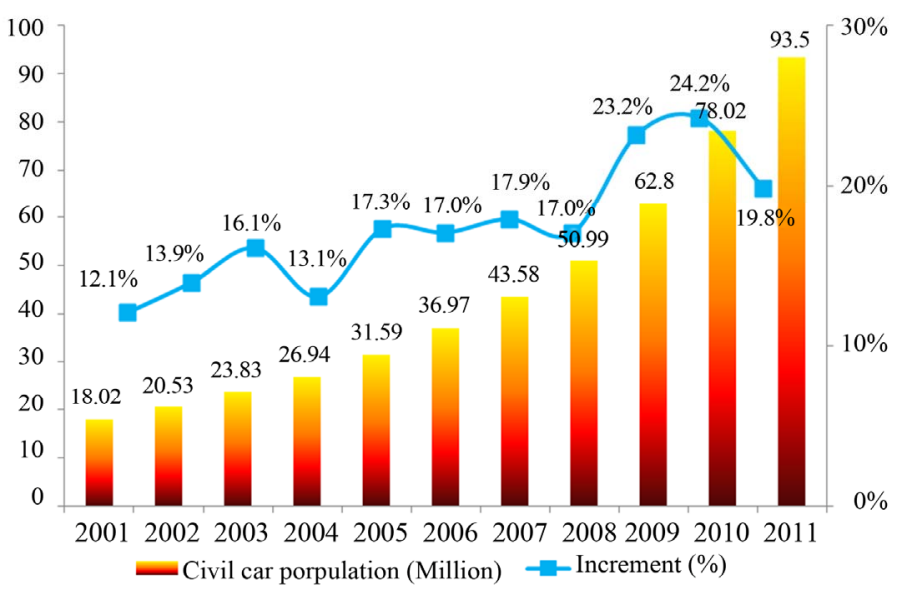

Figure 2. Civil car population in China in 2001-2011. 


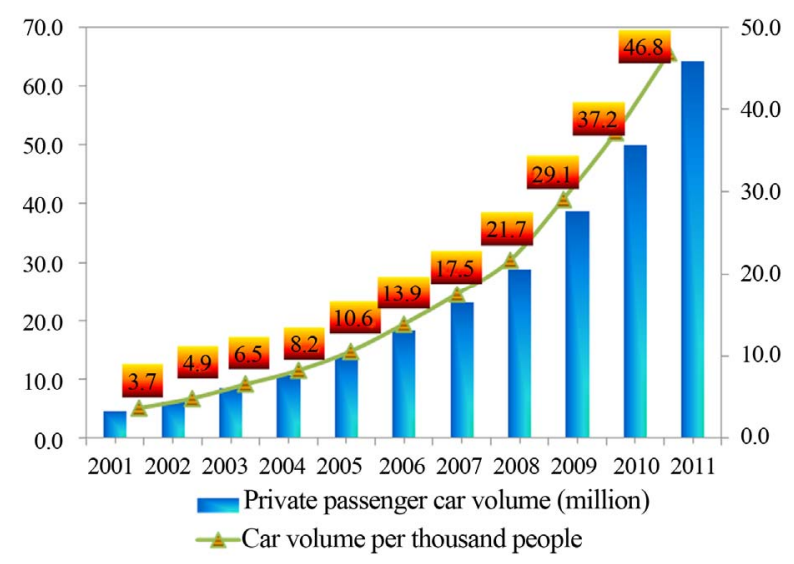

Figure 3. Car volume per thousand people in 2001-2011.

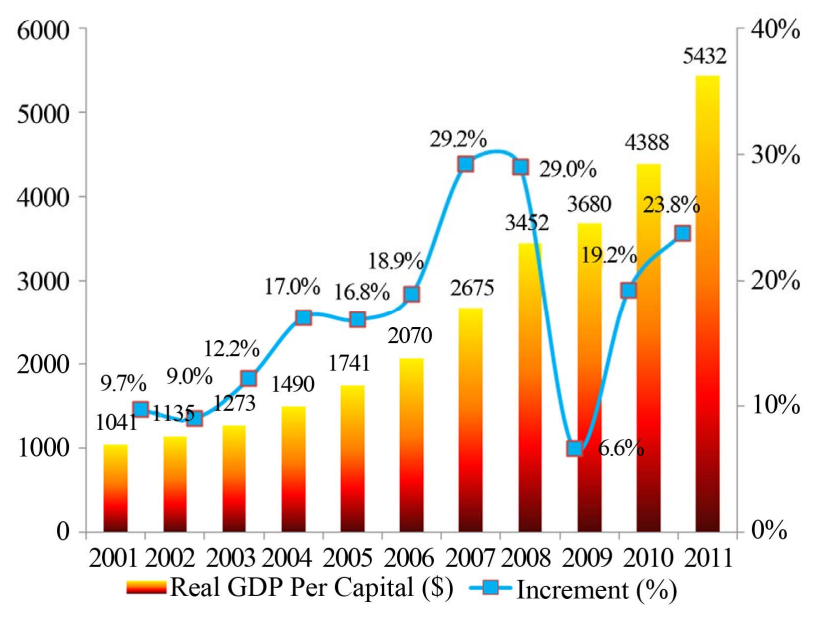

Figure 4. Real GDP per capital in 2001-2011.

enhance the development of used car market in China. In a relatively long period, the auto and used car demand will keep a vigorous stage. The State Development Center and Auto Engineering Association estimated that the total vehicle demand in 2030 will be 32.43 million, with $8.8 \%$ annual increment [6], and the car volume per thousand people will exceed 100 . This increase will stand for a relative long period (Table 1).

\subsection{Policy Analysis}

Apart from consumer demand, several government policies and regulations have boosted the used-car market.

- The Administrative Measures on Used Cars, released in 2005, are the primary regulation governing the used-car market. The measures introduced a competition mechanism that allows OEM-authorized auto dealerships to run used-car businesses. The measures also regulate different parties_-including trading markets, agents and operators-and strengthen the administration of organizations that appraise the value of used cars.
- The Notice on Upgrading the Used-Car Trade Market was announced by the ministries of Commerce and Finance in July 2009. The circular aimed to improve the used-car industry. Initially, the PRC government selected 10 provinces and municipalities-Beijing, Hubei, Jiangsu, Jiangxi, Liaoning, Shandong, Shanghai, Shenzhen, Tianjin and Zhejiang-to receive fiscal funding to conduct pilot programs that focused on the management and information on used-car transactions to improve transparency.

- The Auto Industry Revitalization Plan, released in 2009 by the State Council, calls for the establishment of a national appraisal and evaluation standards system and a temporary ownership registration system. The plan also calls for adjusting the value-added tax rate on used car transactions and encourages dealerships to participate in vehicle replacement programs.

- The Twelfth Five-Year Plan encouraged consumer to purchase energy saving and environment vehicle. Series vehicle subsidy and tax reduction on low emission and new energy vehicle were implemented, which have direct influence on the future used car market. There would be increase in low emission and new energy used car in the future [7].

\section{Current Status of Used Car Market}

\subsection{Trade Scale Kept Steady Growth}

Used car market increased dramatically in China from 2001. The trade volume rose from 0.37 million to 4.79 million in 2012, increased by 13 times. The average increment from 2001 to 2012 was 29.9\% (Figure 5).

The ratio for used car and new car increased from 0.16 to 0.23 , averagely 0.24 from 2001 to 2011, nationwide (Figure 6). In some advanced area, like Beijing, the ratio already reached 1:1 in 2011. Along with the expansion of new car market, used car market was enhanced, conesquently. It is estimated that the trade of used car and new car will come to 1:1 in 10 to 15 years in China.

Consequently, the transaction money for used car trade increased steadily, which rose from 13.2 Billion Yuan in 2001 to 263.6 Billion Yuan in 2012. The annual increment was $33.7 \%$ (Figure 7). The proportion of used car

Table 1. Estimation of auto demand and Parc.

\begin{tabular}{ccccc}
\hline & \multicolumn{2}{c}{ Auto demand/million } & \multicolumn{2}{c}{ Auto Parc/million } \\
\hline Year & 2020 & 2030 & 2020 & 2030 \\
Saloon car & 13.78 & 22.04 & 93.99 & 194.83 \\
Passenger car & 4.36 & 5.41 & 31.33 & 47.20 \\
Truck & 3.70 & 4.98 & 26.39 & 37.84 \\
Total vehicle & 21.84 & 32.43 & 151.71 & 279.87 \\
\hline
\end{tabular}




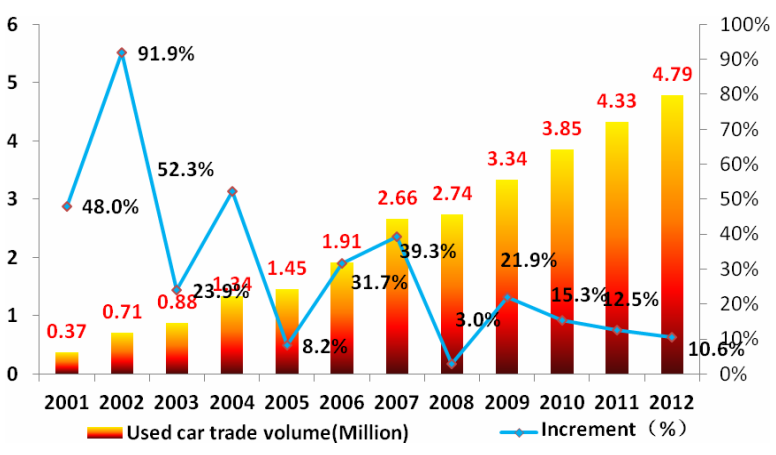

Figure 5. Used car trade volume from 2001 to 2012.

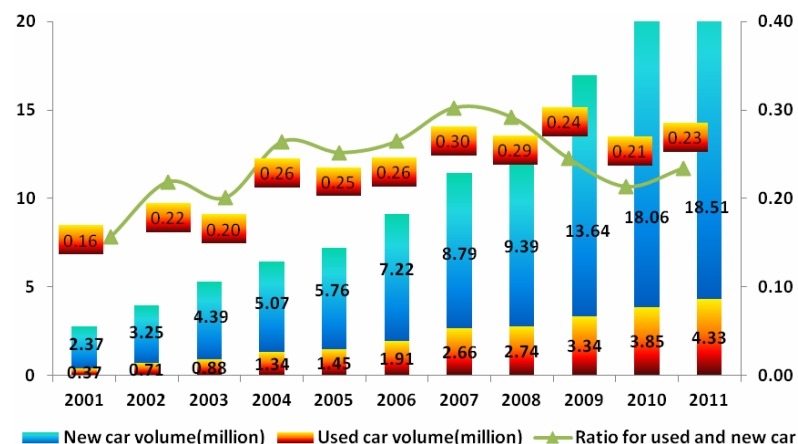

Figure 6. Ratio of used car and new car.

market in auto industry increased steadily, with the average proportion of 5.5\% from 2004 to 2010 (Figure 8) [7].

The growing used car market is becoming the most important part of auto industry, which provide the foundation for leaping development.

\subsection{Used Car Trade Kept Optimized}

After years of rapid development, the trade structure is optimizing. Along with the trade volume increase, saloon car gradually took major proportion in used car trade. After 2008, saloon car account for more than $50 \%$ of used car market share (Table 2).

In the used car market, domestic brand car had the absolute dominant position, which accounts more than $95 \%$. On the car age, even with decrease, used car in 3 - 10 years still took the leading position, which still had $75 \%$ share in 2011. Trade of used car below 3-year increased over the last few year, with 18.74\% share in 2011 (Figure 9).

Obvious regional difference was observed in China's used car market. According to the statistics from China Automobile Dealers Association, used car trade concentrated in the developed area, is shown in Table 3. The first fifth regions account for $55.14 \%$ for used car trade in China, while the first tenth regions account for $77.02 \%$. However, slight decrease was observed in those devel-

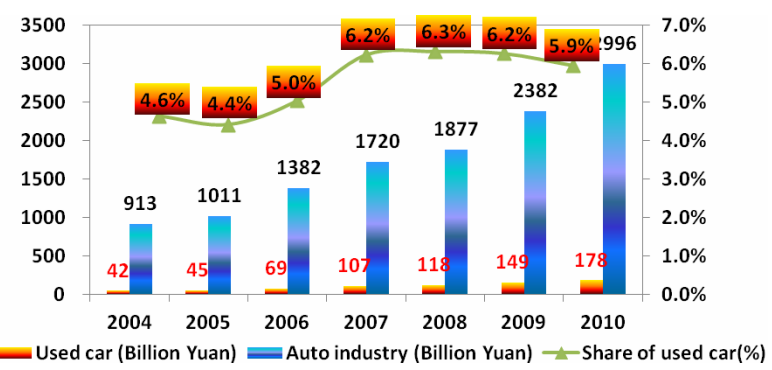

Figure 7. Used car transaction money from 2001 to 2012.

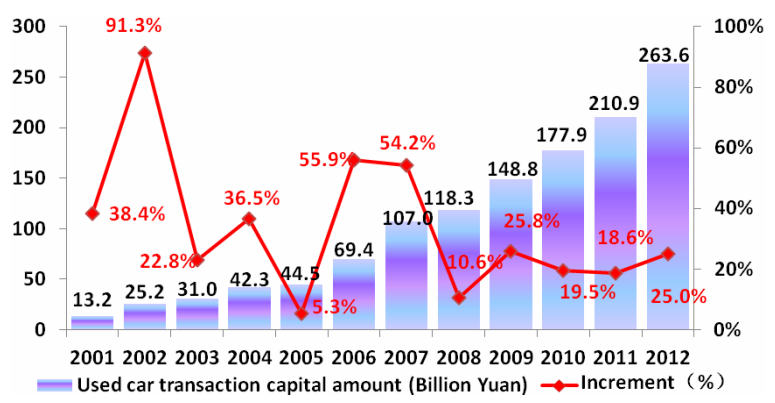

Figure 8. Used car transaction money from 2001 to 2012.

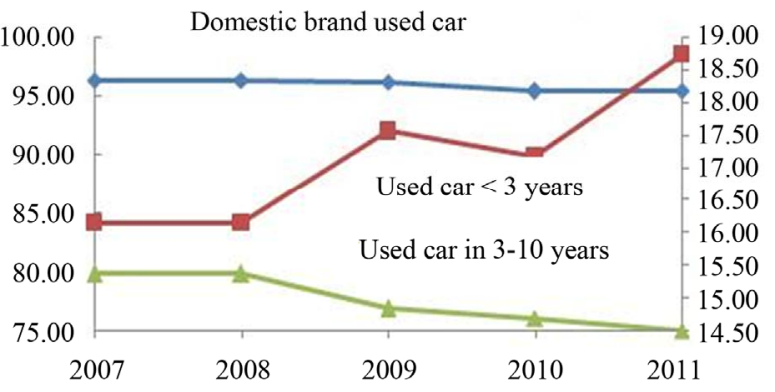

Figure 9. Brand and year feature for used car market.

oped regions. This was probably due to the high level of used car trade in previous years already reduced the market demand.

For the less developed area, rapid development was observed. Even with low market share, auto market was driven by the fast economy growth. The huge market potential was released, thus the used car trade increased very fast.

Besides that, used car trade was mainly in local area. In 2010, local registered used car account for $88.27 \%$ of the total volume. This was due to the complex ownership transfer and registration procedure for cross regional transaction, and high cost. This had significant effect on rational circulation of used car.

\subsection{Purchasing Pattern Changed}

As a matter of fact, growth in the second-hand car market surpassed the sales growth of new cars. Used car grew by near $20 \%$ in volume terms in 2011, reaching over 4.3 
Table 2. Trade structure of used car market in China from 2001 to 2010.

\begin{tabular}{|c|c|c|c|c|c|c|c|c|c|}
\hline \multirow[b]{2}{*}{ Year } & \multicolumn{3}{|c|}{ Truck } & \multicolumn{3}{|c|}{ Passenger car } & \multicolumn{3}{|c|}{ Saloon car } \\
\hline & $\begin{array}{c}\text { Volume } \\
\text { (Thousand) }\end{array}$ & $\begin{array}{c}\text { Increment } \\
(\%)\end{array}$ & $\begin{array}{c}\text { Proportion } \\
\text { (\%) }\end{array}$ & $\begin{array}{c}\text { Volume } \\
\text { (Thousand) }\end{array}$ & $\begin{array}{c}\text { Increment } \\
(\%)\end{array}$ & $\begin{array}{c}\text { Proportion } \\
\text { (\%) }\end{array}$ & $\begin{array}{c}\text { Volume } \\
\text { (Thousand) }\end{array}$ & $\begin{array}{c}\text { Increment } \\
(\%)\end{array}$ & $\begin{array}{l}\text { Proportion } \\
\text { (\%) }\end{array}$ \\
\hline 2001 & 84.6 & 22.85 & 22.85 & 83.1 & 53.31 & 22.46 & 139.7 & 45.27 & 37.75 \\
\hline 2002 & 163.4 & 22.91 & 22.91 & 172.2 & 107.1 & 24.14 & 243.2 & 74.06 & 34.09 \\
\hline 2004 & 285.0 & 21.25 & 21.25 & 344.8 & 57.37 & 25.71 & 459.2 & 39.63 & 34.00 \\
\hline 2005 & 332.7 & 22.94 & 22.94 & 396.0 & 14.85 & 27.3 & 531.9 & 15.82 & 36.68 \\
\hline 2006 & 360.1 & 8.23 & 18.89 & 453.3 & 14.49 & 23.79 & 819.3 & 54.03 & 42.99 \\
\hline 2007 & 455.4 & 17.14 & 17.14 & 644.5 & 24.25 & 24.25 & 1295.3 & 58.1 & 48.74 \\
\hline 2009 & 572.2 & 37.49 & 17.14 & 567.8 & 11.94 & 17 & 1718.5 & 20.42 & 51.47 \\
\hline 2010 & 596.1 & 4.17 & 15.48 & 623.4 & 9.8 & 16.18 & 2098.2 & 22.1 & 54.47 \\
\hline
\end{tabular}

Table 3. Top ten used car trade areas in China from 2008 to 2011.

\begin{tabular}{|c|c|c|c|c|c|c|c|c|}
\hline & \multicolumn{2}{|c|}{2008} & \multicolumn{2}{|c|}{2009} & \multicolumn{2}{|c|}{2010} & \multicolumn{2}{|c|}{2011} \\
\hline Rank & Area & $\begin{array}{l}\text { Trade volume } \\
\text { (Thousand) }\end{array}$ & Area & $\begin{array}{l}\text { Trade volume } \\
\text { (Thousand) }\end{array}$ & Area & $\begin{array}{l}\text { Trade volume } \\
\text { (Thousand) }\end{array}$ & Area & $\begin{array}{l}\text { Trade volume } \\
\text { (Thousand) }\end{array}$ \\
\hline 1 & Guangdong & 500 & Guangdong & 617 & Guangdong & 693 & Guangdong & 588 \\
\hline 2 & Beijing & 296 & Shandong & 358 & Shandong & 399 & Shandong & 316 \\
\hline 4 & Shanghai & 216 & Sichuan & 318 & Beijing & 351 & Beijing & 237 \\
\hline 5 & Sichuan & 208 & Shanghai & 256 & Shanghai & 311 & Shanghai & 205 \\
\hline 6 & Shandong & 164 & Zhejiang & 237 & Zhejiang & 245 & Zhejiang & 173 \\
\hline 7 & Henan & 155 & Henan & 219 & Henan & 232 & Henan & 170 \\
\hline 9 & Tianjin & 92 & Chongqing & 108 & Yunnan & 133 & Yunnan & 127 \\
\hline 10 & Liaoning & 87 & Tianjin & 87 & Chongqing & 111 & Chongqing & 96 \\
\hline
\end{tabular}

Note(s): trade volume in 2011 was the sum for the first three quarters.

million. Indeed, as this trend intensifies, the used car segment will outstrip the new car segment in absolute terms as well. More specifically, given the current trend, almost 19 million used cars are expected to change hands in 2017. That translates into an impressive compounded annual growth rate of over $30 \%$.

One important reason for this change is the purchasing pattern of Chinese consumers. On average, $60 \%$ of Chinese car owners replace their cars every three years much more frequent than other national car markets. This disposition is more apparent in the high-end segment. Here, automobile turnover is particularly strong due to fast-changing demands from wealthy individuals and a purchase pattern that closely correlates with their businesses' profitability. Cars that have barely been used enter the second-hand auto market, attracting new buyers in the process.

Moreover, consumer attitudes are changing. From being viewed as mere status symbols, cars are now increasingly being bought for reasons of functionality and transportation. Additionally, as most people currently buy cars for their first time, they will not be as willing to spend a fortune on a new car. Especially as government policies are now helping car penetration deepen and spread to rural areas and lower-tier cities in China, where an estimated 700 million people live and purchasing 
power is much weaker. So, second-hand cars are becoming viable and desirable options for an increasing number of Chinese.

With the increased supply of used cars to the auto market and the Chinese becoming more comfortable with the idea of second-hand car purchases, this segment is set to grow substantially in the coming years. Although there are some concerns, such as absence of trust between buyer and seller, as the market becomes more established and formalized through authorized dealerships, this problem will likely diminish in the future. And despite governmental policies that largely block second-hand cars from first-tier city markets, they are more attractive options for Chinese living in other areas, especially in poorer, rural areas and lower-tier cities. So, significant expansion of the second-hand car market is imminent and this creates many opportunities for used car trade and related companies [8].

\section{New Features of Used Car Market}

\subsection{Issues of Used Car Market}

As one of the important parts of auto market, used car market kept 20\% - 30\% increase annually. However, the used car market is still in the preliminary stage, compared to the advanced market in western countries. Several dominant issues were as follows.

First, lack of integrity in used car market. The lack of trust between buyer and seller currently remains a huge problem impeding the used car market in China. Chinese consumers, have few resources to help them understand the value of older vehicles. Used car broker often makes traps for consumer for high profit. There are quality, price and legal risk for consumers. And few mechanics are experienced enough to value cars independently. Due to the lack of trust, many potential used car demands cannot transfer into real market demand. Some foreign automakers are hoping to address this problem by setting up programs to sell certified pre-owned cars with warrantee protection. As the used car market continues to evolve, this issue would be solved.

Second, lack of used car evaluation criteria. Currently, there was no systematic used car value assessment criteria and residual value releasing system. On the national side, no rule proclaimed for used car evaluation and value assessment. In practical used car trade, car evaluation is mostly subjective evaluation, only few companies have specialized equipment. Thus the evaluation result depends on the experience and responsibility of estimator, which weaken the fairness and rationality. When residual value assessment, simple average life span depreciation were used, without rational basis and reference, which reduce the fairness of value measurement.

Third, lack of after-sell service systems. The used car market only had the function for industry and commercial bureau verification, and registration, did not have essential service function, facility and service method. One package service has been provided in new car market, but not in used car market. This is far more behind advanced countries. Due to the lack of proper service system, the confidence of consumer was affected, and the expansion of used car market was restricted.

Fourth, incomplete policies and regulations for used car market. Access restriction is quite low in China, which result in low technical ability, poor management and irregular transaction, and weaken consumer's confidence. The tax difference for different trade bodies for broker (0\%), company (2\%), auction (4\%), and trade market $(0 \%)$, result in chaos and unfairness in used car market $[8,9]$. There is no systematic used car evaluation and assessment criteria. The irrational and subject evaluation and assessment result from different personnel reduced the real indication on car real value, which restrict the market development. A rational evaluation system should be established nation-wide.

\subsection{New Feature of Used Car Market in China}

1) Strong policy support for upper development

In recent years, policy support is the most important booster for used car market. Series direct or indirect policy has been released, and facilitate an favorable environment for used car market. Encouraging used car market development has been placed in government work report and plan, which confirmed the basic macro-policy direction.

The policy support has been directly put into practice on the used car trade market, which already makes the shift from outside environment support to direct fostering on used car trade market. The most important one is the Demonstration Project of Used Car Trade Market Upgrading and Reconstruction. The project was executed by the Ministry of Commerce and Finance. 40 used car trade markets were included in ten provinces. The emphasis was on the market environment and service facility, and management system. Series technical and operational supports were provide by the government. Information technology was widely used to promote national information interconnection and interaction, thus to build the foundation on national market and circulation.

The application of these policies, were not only the support from government, but also the concept education for the whole used car trade and circulation industry. The aim was to reform and upgrade the mode of used car trade, enforce scale operation, and promote cross-regional used car transaction $[8,10]$.

2) Expansion of market scale and irradiation loop

After several years of development, the used car market in the key cities as the core is becoming the basic 
trend direction for the nationwide integrated market. Due to the regional discrepancy in China used car market throughout the provinces, the gradient difference in used car consumer can be achieved for the market development. This was confirmed by the experience in developed countries.

The first priority is to taking advantage of radiation and leading role of core cities, to form regional used car market. With the market development, the seamless connection between regional market can be achieved. Then, the used car transfer gradient can be established from developed area to less developed area, thus to form the unified national market.

The used car in the developed area is transferring to the less developed area, along with the demand changing from newly-increased to renew. This will be one of the most important features for China's used car market.

3) Remarkable concentration increase in used car trade

According to the experience in used car market in developed countries, large-scale used car trade is always accompany with the arising and developing of wholesale. For China's market, the used car wholesale mainly to auction is gradually arising, which will be one of the important symbol of large-scale market development. The advanced wholesale business provides strong support for the large-scale used car trade. It is the foundation for cross regional used car transaction, and operation efficiency improvement. Thus the operational transfer cost can be reduced, and improve the comparative advantage in used car price, to promote used car consumption. It is essential to have gradient distribution of new car and used car, to enhance the maturity of China's auto market.

Fundamental changes will take place in the traditional small workshop operation mode. Used car broker company with certain scale and with ability for cross regional transaction will arise in the market, and large-scale used car trade group will also grow. The small scale broker will be forced to quit the market. Thus, the obsessed issue characterized in small, scattered and disordered used car trade will be solved.

Along with the change, professional division will be enhanced for the used car service companies. Integrated used car company will be replaced by specialized purchasing company, wholesale company and retail company. More specialized service and trade company will arise, such as auction company, third-party detection service company, evaluation and assessment company and so on [11].

4) Important role of brand used car

Brand used car from car manufacture started from 2004. And great development has taken place in the recent years. Most of the car manufactures initiated their strategy and used car trademark in the brand used car, such as Chengxin, Anji from SAIC Motor, Certified used car from FAW-Volkswagen, Anxin from FAW TOYOTA Motor, AAA from FAW Audi, and Xiyue used car from GAC HONDA, and so on.

Replacement of used car is becoming the main mode for brand used car. Competition among different used car brands went deep. There are around 1000 auto dealer involved in the used car replacement. As $4 \mathrm{~S}$ shop is gradually becoming the main brand used car source and trading place, the advantage of dealership is more and more obvious. On the basis of advantage in brand influence and, maintenance and service, brand used car will be the major proportion of used car market [12].

5) Trading service platform establishment will be the main content of used car market

Under current circumstance, trading service platform establishment is quite essential for the used car market in China. Used car trade related testing, evaluation, assessment and other service can be provided in the platform for both individual trader and dealer. This platform includes replace platform between new and used cars, service platform among manufactures, and alliance platform among trade market nationwide [10].

Service platform is required to joint new car and used car trade service, due to the replace business majored used car trade in China. Brand used car rely on the platform to achieve replacement business and internal resource interchange among 4s shops. Dealership can use the platform to enforce used car source integration and cross-regional transaction. For professional, large-scale and regional demand, traditional trade market and broker also need this platform. Derived services like finance and insurance also rely on the platform to business development.

\section{Conclusions}

Environment analysis showed that used car market will be strongly enhanced by the blooming of auto market, rapid GDP growth and policy support. The used car trade experienced a steady trade scale increase and structure optimization. Along with the purchasing pattern changing, significant expansion of the second-hand car market is imminent, even with hinder issues such as lack of integrity, evaluation criteria and after-service system, and incomplete policy and regulation.

The new features of China's used car market were identified. First, strong policy support will promote its upper development. Second, both market scale and market irradiation loop will enlarge. Third, there will be remarkable concentration increase in used car trade. Four, brand used car will gradually take an important role. Finally, trading service platform establishment will be the main content of the used car market. The market feature indicated that a major turning point was taking place, 
which showed that China's used car market is making the shift from the subordinate position to one of the dominant positions in the auto industry. China's used car market is expected into a high speed, up-going development passage.

\section{Acknowledgements}

This work is sponsored by the 12nd Five-year Support Program in Shanghai University of Engineering Science (2012-09-nhky) and Shanghai Automotive Educational Foundation Project "Used car business mode research under new market circumstance”.

\section{REFERENCES}

[1] A. D. Little, “China's Automotive Market,” Automotive Viewpoint, 2011.

[2] China Automobile Dealers Association, “2010 China Auto Market Yearbook,” China Commercial Publishing House, Beijing, 2010.

[3] China Automobile Dealers Association, “2012 China Auto Market Yearbook,” China Commercial Publishing House, Beijing, 2012.

[4] X. B. Sun, "Contribution of Used-Car Business for OEM and Implement Strategy,” MBA Thesis, Shanghai Jiao
Tong University, Shanghai, 2011.

[5] X. C. Li, "Effect of Real GDP per Capital on Private Car Demand," Special Zone Economy, Vol. 1, 2010, pp. 284-285.

[6] State Information Center and National Development and Reform Commission, "Forecast of China's Auto Market in 2012,” China Machine Press, Beijing, 2012.

[7] China Automobile Dealers Association, "2011 China Used Car Industry Development Report,” Beijing, 2011.

[8] IPSOS in China, "Related Policy Analysis on Used Car Market Standardization and Promotion Development," China Motor, No. 2, 2011, pp. 32-35.

[9] China Automobile Dealers Association, "2011 China Auto Market Yearbook,” China Commercial Publishing House, Beijing, 2011.

[10] Z. Y. Luan, "Research on the Current China Used Car Brand Marketing Model,” Master Thesis, Jilin University, Changchun, 2011.

[11] H. Zhang and A. W. Zheng, "Current Situation Analysis and Development Strategy of China's Used Car Market," Auto Industry Research, No. 7, 2012, pp. 10-13.

[12] Industry Economy Division in Development Research Center of the State Council, China Association of Automobile Manufactures, Shanghai VW, "2012 Development Report on China's Auto Industry,” Social Science Academic Press, Beijing, 2012. 